\title{
“Cultural Intelligence” During ERP Implementation: Insights from a Thai Corporation
}

\author{
Régis Meissonier ${ }^{1}$, Emmanuel Houzé $e^{1} \&$ Liette Lapointe ${ }^{2}$ \\ ${ }^{1}$ IAE School of Management, Montpellier University, France \\ ${ }^{2}$ Faculty of Management, McGill University, Quebec, Canada \\ Correspondence: Régis Meissonier, IAE School of Management, Montpellier University, France. E-mail: \\ regis.meissonier@gmail.com
}

Received: September 17, 2014

Accepted: October 8, 2014

Online Published: November 25, 2014

doi:10.5539/ibr.v7n12p14

URL: http://dx.doi.org/10.5539/ibr.v7n12p14

\begin{abstract}
Much attention has been devoted to challenges related to ERP implementation. However, there is a wealth of papers that are focusing on cultural issues related to ERP depending the country they are implemented. The objective of this article is to analyze and to illustrate how project managers achieve ERP implementation whereas users face cultural changes concerning the way new tasks and business processes must be done? It differs from the perspective considering IT adoption as depending primarily on IT characteristics and organizational needs. We posit that ERP acceptance/resistance cannot be reduced to use behaviors taken at face value but that they must be analyzed considering their underlying cultural dimensions. The case study was done at Eastwater, a corporation in charge of water distribution across Thailand and that succeeded into implementing SAP in only one year. The semi-structured interviews done with project managers and consultants of the company reveal how cultural values shared by employees were used as change management vectors, showing for example how the project director used the "Bunkhun" values to legitimate the ERP adoption and force users' acceptance of the ERP. The result can help managers to better deal with observed misfits between organizational values and IT project, so that it does not ultimately become an obstacle to user acceptance.
\end{abstract}

Keywords: Enterprise Resource Planning (ERP), culture, change management, Thailand, Buddhism

\section{Introduction}

In both research and practice, much attention has been devoted to challenges related to enterprise systems implementation. A large number of enterprises have implemented ERPs over the last decades (van Vuuren \& Seymour, 2013) with different motives. For large corporations, these investments were especially perceived as the opportunity to get an integrated information system, to harmonize and rationalize processes across business units and subsidiaries, etc. For small or medium enterprises, ERP projects were often motivated by the need to replace outdated business software's or to adopt modules required by business partners (in the case of sub-contractor SMEs in particular). Today, ERPs represent the most important cost item of the information technology (IT) budget of corporations. However, their implementation results remain far from stellar, with failure rates exceeding 50\%, even when implementations are supported by consultants and best practices (Hung, Yu, Chen, \& Hsu, 2012). Despite the fact that ERP projects represent such a high-cost high-risk endeavor, business organizations are still choosing to invest precious financial, human and time resources in these projects. Indeed, enterprise systems have become IT standards in most of business sectors. In other words, an additional reason for ERP growth is the IT alignment fashion that can be observed around the world.

In IT research, there is a wealth of papers that are focusing on issues related to ERP (Seddon, Calvert, \& Yang, 2010; Strong \& Volkoff, 2010). Studies have revealed that several organizational change issues are in terms of 'fit' between the organization and the information technology (IT) implemented. Most of these studies have highlighted task-oriented issues related to user assimilation of new business processes imposed by ERP. One of the key causes of misfit in IS implementation projects relates to the values endorsed by actors (Leidner \& Kayworth, 2006; Walsham, 2002). The system to be implemented can be perceived as inconsistent with the dominant values of the organizational (Markus \& Robey, 1983). This is particularly true in the case of ERP because imposing processes designed from "best practices" observed in worldwide leader companies and, as a consequence, a unique western-oriented managerial paradigm (Wagner \& Newell, 2004). Thus, one can assume 
the managerial processes constrained by an ERP as likely to be dissonant in firms based in countries where business practices are shaped by contrasted cultural principles (Meissonier, Houzé, \& Bessière, 2013). Thus the research question of this article is: how project managers succeed into making ERP implementation being accepted by users facing cultural changes concerning the way new tasks and business processes must be done?

This article differs from the perspective considering organizational IT adoption as depending primarily on IT characteristics and organizational needs. We argue that IT acceptance/resistance cannot be reduced to use behaviors taken at face value but must be analyzed along their underlying cultural dimensions. To illustrate this perspective we focused the research in Thailand because of its culture embedded with Buddhism. On the basis of the literature review, we apply a "cultural intelligence" (Earley \& Ang, 2002) frame, which allows understanding how these cultural misfits translate into different user reactions and how these can be accommodated. The empirical part develops a case study analysis of Eastwater, a corporation located in Bangkok. The semi-interviews technique done with project managers and consultants of the company allowed us to capture the way the local culture of the company shaped the way an ERP has been implemented and accepted by users. From a practical perspective, the study can help managers to better deal with observed misfits between the organizational values and the IT project, so that it does not ultimately become an obstacle to user acceptance.

\section{Literature Review}

In existing IS literature, there is a wealth of papers about the way ERP can raise conflicts when implemented in organizations. User resistance is all the more likely that enterprise systems are often mandatory projects. Then, users have to cope with an imposed IT can develop negative attitudes about its functionalities or its user-friendliness. Lot of empirical research revealed issues in terms perceived "ease of use" or "usefulness" (Davis, Bagozzi, \& Warshaw, 1992; Davis, 1989; Venkatesh, 1994), and provided useful observations about personal characteristics associated, such as readiness to change (Walczuch, Lemmink, \& Streukens, 2007), and personal competences (Kwahk \& Lee, 2008). Actually, IT implementation often requires actors to develop new professional skills in order to assimilate job transformations involved (Besson \& Rowe, 2001; Markus, Tanis, \& Fenema, 2000). For example, before the "ERP wave" of the 90's, accounting departments mainly spent time into collecting, aggregating and synthesizing financial data. Enterprise systems allowed automating and saving time to do these processes. As a consequence, they dramatically transformed the tasks assigned to accounting employees and one observed new missions assigned in terms of recommendations and propositions to be addressed top managers (Bernard, Rivard, \& Aubert, 2004).

ERP implementation may also raise conflicts about the way business processes are modified or transformed to fit with the project requirements in terms of reengineering. For example, in civil engineering project management, ERP changed the way project supervisors, architects and artisans (electricians, plumbers, etc.) collaborated (Gilbert \& Leclair, 2004). Formerly, they did not have to communicate to colleagues the details of calculations on which their analyses were based. The integration of processes associated with IT looks like a management of interdependencies (Rockart \& Short, 1995) by which an actor becomes a prescriber for his colleagues. When ERP modules are implemented in standard version ("vanilla implementation") they represent one of the most well-known conflict drivers (Lee \& Myers, 2004) because of the business processes imposed on employees without too much consideration of organizational specificities (Davenport, 1998; Lim, Shan Ling, \& Chee Wee, 2005; Markus, Tanis, et al., 2000). These benchmarked processes are based on "best practices", typically originating from leader firms in America or Europe. In other words, an ERP imposes an "epistemological posture" to firm units and sub-units (Wagner \& Newell, 2004) that is linked to Western managerial practices. Beyond issues and resistances due to process change, some cultural conflicts may arise from inconsistency with values and beliefs shared by actors (Bhattacherjee, Davis, Hikmet, \& Kayhan, 2008; Bhattacherjee \& Hikmet, 2007; Kohli \& Kettinger, 2004; Leidner \& Kayworth, 2006). In the IS literature based on the interaction theory (e.g., Joshi 1992), it is suggested that the true motives of IT conflicts are not the ones about the system but users' perceived values and social content gain or loss before/after system implementation (Jiang, Muhanna, \& Klein, 2000; Kendall, 1997). As a consequence, the interpretations of resistance, as expressed by users toward ERP project, ought to be not limited to face value. Indeed, relying on system inconsistencies or organizational misalignment to explain resistance is probably a more comfortable strategy than the ones consisting of expressing underlying individual socio- political challenges on behalf of cultural specificities (Meissonier \& Houzé, 2010). A lot of conflicts in organizations however result largely from cultural factors that originate outside the particular lateral relationship under consideration or which antedate the relationship (Thompson, 1961; Walton, Dutton, \& Cafferty, 1969).

A large number of definitions and characterizations exist in the literature about culture, and probably a first challenge for an article on this topic is providing a satisfactory description of this literature. A large part of the 
cross-cultural research that is published relies on Hofstede (1991), which considers culture as a collective mental program shared among members of a country, a region, or a group; and unshared with non-members. With this theoretical lens, analyzes often take the form of descriptive comparisons of national cultures based on pre-defined cultural dimensions of the Hofstede model. This stream of research provides some valuable interpretations of international projects failures (subsidiaries implementations, exportations, strategic alliances, etc.) as it reveals fundamental concepts (time, power, risk, success, etc.) being perceived differently by partner countries. However, this theoretical basis fails into going beyond cultural dissonance and providing an understanding about how it may be possible to attain a cross-cultural congruence.

One way to aggregate the dominant schools of thought about organizational culture is using the twofold theoretical frame suggested by Bourdieu (1979). On the one hand, culture shapes behaviors (structuralist approach). On the other hand, the ways individuals behave also shape culture. Hence, the culture of an organization is social construct (constructionist approach). The interest of Bourdieu theory is putting forward this twofold approach as not exclusive but as two sides of a same social process. It represents a framework embedded in managerial processes, practices and beliefs. It is considered as a challenge to allow corporations to develop group identity (Handley, Sturdy, Fincham, \& Clark, 2006; Wenger, McDermott, \& Snyder, 2002), intellectual asset and knowledge creation (Alavi \& Leidner, 2001), and to sustain competitive advantage (Alavi, Kayworth, \& Leidner, 2005; Drucker, 1998; Teece, 2003).

According to Schein (Schein, 1984), artifacts are the most visible manifestations of organizational culture. Ceremony, architecture, technology, office layout, behavioral patterns (dresses, jargons, etc.), business stories, etc., represent artifacts that signification is to create and maintain the identity of the group. Like rites and symbols, their objective is to create a visible distinction between persons who are in conformity with social expectations of the group and the ones who are not. In this sense IT may be viewed as artifacts (Orlikowski, 1992) instrumenting processes designed in line with the values and the basic assumptions of the organization (Meissonier et al., 2013). However, most of ERP implemented in corporations nowadays are implemented in a standard version ("vanilla implementation") not tailored to organization needs and cultural specificities. In other words, one can assume this artifact as dissonant with the existing culture of the firm. IS researchers have studied the effects of national and organizational culture on diverse subjects like IT project development (Dubé, 1998; Ngwenyama \& Nielsen, 2003; Robey \& Markus, 1984), IT adoption (El Sawy, 1985; Hoffman, 2000; Jarvenpaa \& Leidner, 1998; Karahanna, Evaristo, \& Srite, 2005), IT acceptance and diffusion (Detmar W. Straub, Keil, \& Brenner, 1997; Detmar W. Straub, 1994), IT usage (Kappos \& Rivard, 2008; Vance, Elie-Dit-Cosaque, \& Straub, 2008), and benefits forms (Gold, Malhotra, \& Segars, 2001; Weber \& Pliskin, 1996). These studies were instrumental in identifying existing cultural characteristics of organizations and show their congruence - or lack thereof - with the IT implemented. However, these studies do not explain how such congruence can be developed over time, despite apparent differences or oppositions between the IT and the practices.

To fill this research gap, we propose to use an alternative theoretical perspective emerging from anthropology and sociology in order to apprehend culture from a more process-oriented point of view (Reckwitz, 2002). In management, Shenkar et al. (Shenkar, Luo, \& Yeheskel, 2008) proposed to replace the concept of "distance" by "friction" to highlight cultural asymmetries as configurations allowing actors to resist, negotiate, learn and assimilate apparent inconsistent habitus. Here, "frictions" are not negative conflicts that exist between individuals, but rather interactions likely to create a common understanding of their cultural differences. In information systems research, Walsham (2002) showed how IT have properties that shapes organizational culture over time. In other words, culture is less a straightforward organizational characteristic than an evolving social construct. This distinction is crucial to evacuate any static interpretation of culture, cultural differences and misalignment issues.

Table 1 summarizes the way of thinking has evolved about "organizational culture" in order to highlight the "cultural intelligence" concept. In parallel, it points out empirical research in IS are mainly "fit-based oriented" and poorly used this theoretical lens to apprehend IT implementation issues. 
Table 1. Theoretical perspectives about "organizational culture"

\begin{tabular}{|c|c|c|c|}
\hline Perspectives & Main authors & Principles & Analysis levels \\
\hline \multirow[t]{4}{*}{ Structuralist } & $\begin{array}{l}\text { Hofstede \& Bond (1988); } \\
\text { d'Iribarne (1989); Hofstede } \\
(1991)\end{array}$ & $\begin{array}{l}\text { Cultures can be analyzed and compared in function of pre-established } \\
\text { dimensions. This approach is at the origin of the "cultural distance" } \\
\text { perspective to analyze international management issues. }\end{array}$ & $\begin{array}{l}\text { Countries, } \\
\text { Organizations }\end{array}$ \\
\hline & $\begin{array}{l}\text { Straub \& El-Shesai }(1998) \text {; } \\
\text { Thanasankit \& Corbitt } \\
\text { (2000); Trauth (2000); } \\
\text { Trauth \& Thomas (1993); } \\
\text { Moores \& Gregory (2000) }\end{array}$ & $\begin{array}{l}\text { Beyond Hofstede pre-established cultural dimensions, empirical research } \\
\text { using alternative investigation methods revealed additional dimensions. }\end{array}$ & Organizations \\
\hline & $\begin{array}{l}\text { Corbitt et al. (2004); Hall } \\
\text { (1997) }\end{array}$ & $\begin{array}{l}\text { Culture is presented as a conceptual map shared by actors. It corresponds } \\
\text { to the codes persons have in mind and the language they use to interpret } \\
\text { their social environment. This perspective is based on the social } \\
\text { construction theory of Berger \& Luckman (1967). }\end{array}$ & Organizations \\
\hline & Hall $(1959,1981)$ & $\begin{array}{l}\text { Culture is considered as a sort of communication with "silent language" } \\
\text { between persons as mark of their value differences. Five "silent } \\
\text { languages" are identified during conversations: time usage (polychronic } \\
\text { versus monochronic), space respected, attitudes toward physical objects, } \\
\text { cordiality level and formalism in decision justification. }\end{array}$ & Organizations \\
\hline \multirow[t]{2}{*}{ Constructionist } & $\begin{array}{l}\text { Sainsolieu (1995); Ouchi } \\
\text { (1978); Alavi et al. (2005); } \\
\text { Bloor et al. (1994); } \\
\text { Dougherty (1992); Jermier } \\
\text { et al. (1991); Stewart \& } \\
\text { Gosain (2006) }\end{array}$ & $\begin{array}{l}\text { Organizational culture is not homogeneous, but a mix of several "cultural } \\
\text { words" (Sainsolieu) of groups of actors. Organizations are represented as } \\
\text { mechanisms of "clans" having their own culture (Ouchi). }\end{array}$ & Organizations \\
\hline & Meyerson \& Martin (1987) & $\begin{array}{l}\text { With difference to the "integrative perspective" that considers culture as a } \\
\text { "glue" reassembling diverse groups of the organization, the "differentiated } \\
\text { perspective" represents organizational culture as a composition of } \\
\text { subcultures. }\end{array}$ & Organizations \\
\hline \multirow[t]{6}{*}{ Evolutive } & Myers \& Tan (2002) & $\begin{array}{l}\text { Studying organizational culture according to its hypothetical specific } \\
\text { parameters does not make sense. Culture is perceived as a temporal and } \\
\text { emerging process. }\end{array}$ & Organizations \\
\hline & Schein (Schein, 1984) & $\begin{array}{l}\text { Organizational culture is composed of three inter-related levels explaining } \\
\text { its dynamic nature. Basic assumptions } \\
\text { Artifacts are the most visible manifestations of organizational culture } \\
\text { (ceremonies, architectures, technologies, behavioral patterns, dresses, } \\
\text { jargons, business stories, etc.). Values are the governing professional rules. } \\
\text { They represent the official philosophy of the firm. Values are general } \\
\text { feelings, more emotional than rational, reflecting the preferences in terms } \\
\text { of expected behaviors in specific contexts. Basic assumptions are } \\
\text { unconscious beliefs that individuals have toward human nature, } \\
\text { relationships toward the environment, time, space, etc. }\end{array}$ & Organizations \\
\hline & Straub et al. (2002) & $\begin{array}{l}\text { According to the authors, culture is composed of several inter-related } \\
\text { layers. They use the "virtual onion" metaphor where the core is } \\
\text { fundamental cultural parameters on which cultural layers strive. }\end{array}$ & $\begin{array}{l}\text { Organizations, } \\
\text { Teams }\end{array}$ \\
\hline & $\begin{array}{l}\text { Martin (2002); Kappos \& } \\
\text { Rivard (2008) }\end{array}$ & $\begin{array}{l}\text { organizational culture is not only "differentiated" (in the sense of Marti } \\
\text { and Mayerson), but also "fragmented". It can involve several } \\
\text { interpretations of the same object (a project, an event, etc.). }\end{array}$ & $\begin{array}{l}\text { Organizations, } \\
\text { Teams }\end{array}$ \\
\hline & Walsham (2002) & $\begin{array}{l}\text { Culture is viewed as a pattern composed of systems of significance, power } \\
\text { and norms. Culture is not intangible; it can be "negotiated" between actors } \\
\text { having different values. }\end{array}$ & Teams \\
\hline & $\begin{array}{l}\text { Earley \& Mosakowski } \\
(2000) ; \text { Earley \& Ang } \\
\text { (2002); Thomas and Inkson } \\
\text { (2004); Thomas (2006); } \\
\text { Gregory et al. (Gregory, } \\
\text { Prifling, \& Beck, 2009) }\end{array}$ & $\begin{array}{l}\text { An organization can develop a "cultural intelligence" allowing exceeding } \\
\text { its own culture to understand and assimilate a foreign cultural model. }\end{array}$ & Teams \\
\hline
\end{tabular}


In this perspective, the concept of "cultural intelligence" has been put forth by an inter-disciplinary group (Ang \& Inkpen, 2008; Earley \& Ang, 2002; Thomas \& Inkson, 2004) to express the capacity of actors to assimilate new cultural contexts. According to Earley and Ang (2002, p. 93), "cultural intelligence" embeds three dimensions. The cognitive dimension corresponds to the actors' needs to understand the fundamental values, beliefs and taboos of others. Such a learning process is, for a large part, based on tacit knowledge because actors are not always being aware of their cultural differences or are being reluctant to express them. The motivational dimension refers to the attitudes actors must have to cope with their cultural differences. It implies some personal qualities like curiosity, empathy and self-determining (Thomas, 2006). The behavioral dimension corresponds to the actual feasibility of cross-cultural practices. It refers to the solution repository actors can create and use in order to reduce cultural bottlenecks, inconsistencies, or misunderstandings.

From a cultural intelligence perspective, cultural differences must not be amalgamated into a "fit - misfit" dichotomy. They are not a priori antecedents of an IT project acceptance or resistance; they are rather revealed and evolved during a project. Such an emerging or enacted (Weick, 1988) take on culture allows overcoming a deterministic approach that would consider congruence between an IS and an organization as a function of the possible adaptation level of the first to the second. To date, the empirical research conducted using a "cultural intelligence" lens has had two main limitations. First, the studies are limited to the group level of analysis and have not been applied to a more holistic organizational level. Second, they have mainly focused on how groups of actors interact with respect to their cultural differences. There is a need to better understand how cultural intelligence, in an organization, is likely to develop following the implementation of a "disturbing artifact" such as an ERP. Indeed, information (Feldman \& March, 1991), and the way information systems are designed (Robey \& Markus, 1984) embeds a high symbolic value. If culture can influence IT adoption and IT usage (Karahanna et al., 2005) conversely, IT can bring about cultural conflicts likely to lead to project abandonment (Meissonier \& Houzé, 2010). Recent empirical research (Rivard \& Lapointe, 2012) showed the importance of managers' responses in managing user resistance.

Using the "cultural intelligence" concept as a theoretical lens allows analyzing actions carried out by managers in order to accommodate perceived cultural inconsistencies during ERP implementation. More precisely, our study aims at filling the existing gap in the IS literature by studying the role of cultural intelligence in managing ERP implementation.

\section{Methodology}

For this study, a qualitative research design primarily based on semi-structured interviews has been deemed appropriate. Using a qualitative, grounded-theory approach, we conducted a case study in an organization in Thailand that has recently and successfully implemented an ERP despite times of difficulties. Two main reasons justify this a posteriori research design for the case selection. (1) The interest of interviewing project managers who are able to talk about their project management experience with insights. Indeed, user reactions (e.g. resistance) represent a complex process that is not always perceptible at the very moment it arises. Therefore, an in situ investigation would not have ensured that it would be possible to identify the actual cultural resistance manifested during ERP implementation. (2) The need to focus on firms that had succeeded to manage the resistance that emerged during the ERP implementation project. Indeed, an investigation done during the "pre-implementation" phase would not have allowed identifying the "effective" actions taken by managers.

We decided to do a case study of a company located in a country where managerial practices were likely to be specific and different from the ones generally observed in American or European where ERP are now largely diffused across business sectors. Historically, Thailand is the only South East Asian civilization that was never colonized by American or European countries. 95\% of the population is Buddhist and Buddhism exerts an important influence on Thai people in the daily life and the way they behave both in private and professional context. It has been less influenced than neighbor's countries by western culture. Since 1990s, the Thai culture has been evolving because of globalization, economic growth and the openness of the ASEAN market in 2015. New transitional values imported from western culture (individualistic performance, material and ownership as sign of success, etc.) are grudgingly infused (Klausner, 1998; Niffenegger, Kulviwat, \& Engchanil., 2006, p. 407). As a consequence, Thai people positively consider Information Technology implementation as a symbol of modernism and success for the country (Vatanasakdagul, D'Ambra, \& Ramburuth, 2010). So, we did not assume some kind of national aversion about ERP systems themselves preventing any possible cultural fit.

As explained below, our interviews have been conducted at Eastwater, Bangkok. Because of the complexity of the organizational and social phenomena that are associated with our research objectives, we ensured open-ended questions allowing us an in-depth understanding of the situation (Boyatzis, 1998; Eisenhardt, 1989; Miles \& 
Huberman, 1984; Yin, 1994). In January 2013, we conducted semi-structured interviews with key actors of the ERP project: the finance director (n-1 level, member of the board of directors and director of the project), two project managers and a consultant in charge of the implementation. These interviews were conducted in English at Eatswater head-office in Bangkok and audio-recorded (around 15 hours). To sustain a dynamic discussion, the researchers alternatively asked the questions of the interview guide. To reduce potential cultural biases in the interpretation of the answers, they solicited the assistance of a native Thai researcher of Burapha University (south of Bangkok), who is an expert in cross-cultural management and Buddhist culture. The interviews were audio-recorded to facilitate data analysis. Notes were taken to record the verbal and nonverbal communication cues of all three informants. Data were analyzed according to the standard methods for analysis of qualitative topics. The iterative analytical process was principally inductive, using a thematic analysis with open, axial and selective coding of the data. It allowed a rigorous analysis of qualitative materials, based on repeated "back-and-forth" between the chosen codes and the interview data. To reduce potential biases of misinterpretation, the researchers compared their notes to agree on a common signification of the collected data. In addition, we relied on secondary data (archives, reports, articles, etc.) related to the history and the activity of the firm. Finally, "confirmatory interviews" were done with one of the consultants we had interviewed to ensure consistency in our analysis. This post analysis phase was important to ensure our own understandings and to make sense of the relationships we had established between the ERP implementation and the culture of the firm.

The analysis process followed an iterative process going from reading the content of data multiple times to analysis. This iterative process was pursued to allow progressive theory development, ideally with an increasing level of abstraction (Urquhart, Lehmann, \& Myers, 2009).

\section{Findings}

Eastwater is the Thai corporation that is in charge of water distribution across the whole country. The company has developed several activities related to water storage, treatment, quality expertise, infrastructure maintenance, etc. It was created in 1992 and totally belonged to the Thai government. Since then, Eastwater has sold part of it, but the state has remained the main shareholder. It is thus still a public corporation.

Initially, the information system was based on specific IT solutions developed with popular software like Cristal Report or Excel. As a consequence, there were issues related to data process redundancies. Lack of data integrity had a negative effect on the top managers' decision making. In addition, the growth of the business outside Thailand was yet another motive to adopt an IS solution consistent with the ones of potential partners, customers and suppliers. Eastwater thus decided to adopt the SAP solution in January 2011. This project was divided into two phases. The first one consisted into implementing the Accounting/Finance and Facility Management modules at the head-office and the five subsidiaries. These two modules were installed on three servers and replaced the existing software solutions. The second phase is planned for 2015 and will involve the implementation of additional modules: Project Portfolio Management, Plant Maintenance and Business Intelligence. The first phase of the project lasted one year with a budget of 55,4 Mbaths (approximately 1,8 million $\$$ USD or 1,4 million $€$ ). So far, more than 300 employees are using the SAP modules.

At the national level, Eastwater has been developing (with its 5 subsidiaries) its business by implementing water pipes in underprivileged areas of Thailand. At the international level, the company participates to cooperation projects with competitors of other Asia countries. The creation of the ASEAN common market in 2015 questions the new business boundaries of Eastwater. At the organizational level, the main objective of the project was based on the need of Eastwater to have a financial and accounting system that would be more efficient and more useful for decision-making. For this reason, the Accounting/Finance module implemented was a cornerstone of the first phase of the ERP project. Some task-oriented i.e. operational issues - most important user resistance were recognized early on:

"In the five subsidiaries, the users were reluctant using SAP and preferred relying on Excel because of its flexibility. After the ERP modules being implemented, we observed during several weeks accounting documents were still made with Excel. We have been forced to carry out a huge data migration, that we had underestimated, to force users adopting the system. At the moment, $80 \%$ of the data of the prior systems has been moved to SAP database. So, it turns out to be the unique database that users have to cope with and to use". (Project manager).

Our data revealed some of the main stumbling blocks encountered during the ERP implementation. As some of them were clearly associated with the Buddhist culture of Easwater, we did not settle for a "first level understanding" and we ensured decoding the formal expressions of the interviewees. Indeed, Thai people are reluctant to talk about resistance or conflicts in the company. Moreover, at the beginning of the interview, we realized that our interlocutors feared that we would consider their corporate culture as a potential barrier to 
modernism and innovation. Additional discussions with a teacher-researcher of Burapha University were very useful to identify cultural underlying problems that had been expressed, at first glance, as purely functional or operational. We do not pretend that we are here covering all the aspects that could have been considered about the culture of the company, but our findings reveal how the project director and the project managers used the hierarchical culture of the company to make the ERP being accepted.

It must be said that the Buddhist culture is totally embedded in the organization as a whole, to the point where Easwater celebrates religious ceremonies. Two major principles of Buddhism in line with the research of Joungtrakul (2009) and Thanasankit (2002) were particularly useful to analyze the data. The first, called "Bunkhun", explains the expected social behaviors of a person (altruistic dimension) and the second, called "Kreng Jai", is centered on the individual himself (hedonistic dimension). These principles have been especially useful in analyzing a difficulty -also apparently purely operational- that concerned the budgetary control process.

SAP imposes by default the need to put together a detailed financial budget that has to be established before a project activity can be created. The project director revealed that most employees (middle managers and as well as executives) were not able to do so. This was less due to negligence or lack of rigor than to existing practices. From a Western managerial perspective, it might appear surprising to start a business project without a budget, even an approximately estimated one. Our analysis leads us to actually conclude that the difference lies in the way the concept of "project" is culturally considered. In Thailand, like in many Asian countries (Hofstede \& Bond, 1988; Hofstede, 1991), the relationship to time is more long-term oriented than in Western countries. For example, starting a project with a supplier or a customer does not mean that business transactions can start just because of a contract has been signed. While business practices are evolving because of globalization and western culture influence, Thai managers still remain reluctant to start directly businesses relationships with unfamiliar enterprises. There is a kind of "trust period" to be respected before doing any significant economic transaction (Joungtrakul, 2004). This period can last several weeks or months before any resources and budget being established. It is totally different from a feasibility analysis and corresponds to privileged moments where people physically get acquainted and have discussions that do not strictly relate to the project. This exchange tends to be disconnected from economical and financial preoccupations but is necessary to establish the relation of dominance between both parts. As consequence, empirical research (Niffenegger et al., 2006; Vatanasakdagul et al., 2010) revealed how B2B projects conducted in Thailand were jeopardized because of the reluctance of firms doing business with firms only met online, or disclosing their inventory data to unknown suppliers.

This dissonance toward time was also salient in job-tasks that relate to reporting processes. For instance, dashboards were provided by employees without all the required data. This inevitably raised problems of reliability of the reports created to support top managers' decision making. The project director recognized that the most disturbing point for employees and users was the rapidity by which strategic decisions must now be made because of the growing competition. In addition, the board of directors made decisions more progressively, in several steps, and employees took more time to complete the required data. It was common to split data reporting over several board meetings; decisions were being made after several months only.

"We no more have time to waste with decision making processes. The challenge is having an immediate and complete access to data in order to decide quicker than we were used to do so far". (Project director).

"Employees were used into establishing temporary documents based on approximate and incomplete calculations. Now, with SAP, they can't validate a process unless all the required details are typed. It is all or nothing! Now we can't afford making delayed decisions. As director, I need an instant access to Key Performance Indicators". (Project director).

Change management has been carried out directly by the finance director (project director) and with his two project managers. The questions asked about the way the ERP had been adapted to the specific needs of the organization got answers that revealed that a mandatory standard implementation was imposed to users.

"At the outset, the decision was made to proceed to a 'vanilla implementation' like it is done everywhere around the world. This is why we decided to adopt SAP because of its leader position. Initially, I was not enthusiastic by the editor proposition because of the cost estimated. However, if in the middle term we need to develop our business through partnerships, we must endorse standard processes. We are not here to change the world, but to be adapted to the world". (Project director).

When asked about users' reactions when the ERP adoption decision was announced, the project director gave an interesting and surprising answer... He completed his argumentation with a non-verbal communication very illustrative of the hierarchical distance culture in the company. 
"We chose key users among middle-managers only. We only took into account their demands. Lower-level employees don't have abilities to understand what the challenge is! We (ndrl: the top managers) only had to explain to them the company gave a one million dollar tool to their disposal, and it was not for nothing! We are the "big ones" and they are the "small ones" (ndlr: he formed a pyramid with his hands), and we must remind them. They said (ndlr: he looked to the sky and imitated an employee asking a question to a superior). 'Sir, why have we to work with this new software now?' (ndlr: he looked to the floor speaking to somebody below him). 'Hey! Now you have to work with SAP because it is the international standard and because we are telling you this is the right way'". (Project director).

If such a verbal and non-verbal communication could, at first glance, be shocking for Western people who are used nowadays to less authoritarian relationships between managers and employees, the above answer needs to be further decoded. When this manager said that "low-level" employees are not able being involved in the project, it must not be considered as a sort of scorn toward social underclasses. Actually he is hinting at a "Phu Noi" ("little employee") who has a strong aversion towards risk and situations where s/he is expected to be making decisions on behalf of a group. A case study (Joungtrakul, 2004) conducted in a Thai engineering company showed that hierarchical distance inhibited the autonomy of IS project teams whose members tended to rely on their superior for any potentially risky decision. At a same hierarchical level, it can be a delicate matter for a "key user" to decide on the appropriateness of system functionalities for all users. We observed here a cultural specificity in terms of project management. Indeed, in the existing literature, one of the commonly acknowledged success factor for ERP project is the ability of the CIO to involve "key users" from the onset of the project (Davenport, 1998; Markus, Axline, Petrie, \& Tanis, 2000). User involvement often takes the form of a challenge but is now seen as a ritual in IS development (Hirschheim \& Newman, 1991). Key users are normally considered as the most able to endorse the changes required by the IS project. Implementation of an ERP is synonym with radical organizational modification, questioning the relevance of prior processes and practices. Like with reengineering project (e.g., BPR), and transformation strategies, the path-dependency of the firm is considered as likely to jeopardize the readiness of the firm to change absorption. At the same time, one cannot expect same rule played by key users in a western cultural context than the one played in Thai cultural context. A case-study research conducted in a Thailand in an engineering project (Corbitt et al., 2004, p. 77), revealed because hierarchical cultural distance, team members tended automatically to rely to superiors for any risky decision to be made. There was an "upward delegation" tendency different than the one expected in western culture as a user delegation of the IS design. It may be hazardous supposing Thai "key users" having same disposal to decide of the suitability of the system to be implemented on behalf of all users. This is related to "Thai culture's high uncertainty avoidance" (Niffenegger et al., 2006, p. 411). The legitimacy of key users and the role of "elders" (hierarchical superiors, middle managers, senior employees, etc.) can be seen as a way to manage uncertainty. The role of devotion and trust in Buddhist culture, the strong sense of hierarchy allows people to feel responsibility as personal, namely placed directly on the individual (Joungtrakul, 2009).

The change management style at Estwater thus took the form of an authoritarian management style. However, real autocratic management styles are not popular in Thailand (Yukongdi, 2010). It became obvious that the hierarchical distance related to the Buddhist culture played a significant role in the "vanilla" ERP implementation. SAP became the main IT system for 300 users in less than one year. However, our analysis of the Buddhist culture incites us not considering this situation as a form of enslavement of employees who fear sanctions or blames. Actually, and despite some personal dissatisfaction, users' acceptance of the ERP was more related to the consideration given by employees to top managers. This point is akin to the "Bunkhun" (or "Katanyu") principle of the Buddhism. "Bunkhun" is often translated as "thankfulness" and corresponds to the gratitude of Buddhists toward the ones providing help. Family members, professors, monks, elders, etc. represent the "building blocks of the moral order" (Niffenegger et al., 2006; Vatanasakdagul et al., 2010). One difference with the Western culture, is that those marks of respects taking the form of rituals in the daily life. The "Bunkhun" determines the behaviors that a person must exhibit depending on the person s/he talks to. For instance, when somebody is thanked for his/her help, his/her face must seem serious ("Phuu mee phrakun") expressing s/he does not consider the other as being liable. Actually, inter-individual relations are structured according to the social categories: adults toward children, professors toward students, elders toward youth, etc. In function of their age, their social rank, their power, their instruction level, people are labelled as "big people" ("Phu Yai") or "little people" ("Phu Noi"). Professional relationships are also governed by these symbolic rules and are characterized by non-confrontation, respect, and deference for authority (Selvarajaha, Meyerb, \& Donovan, 2013). As representative of power and professional experience, hierarchical superiors are considered as "Phu Yai" and deserve similar gratitude from the part of the employees. The management style in Thailand can be considered as "family oriented" both in large and small firms. Managers are expected to behave as "good fathers", paying 
attention to their employees (Komin, 1990; Niffenegger et al., 2006). This status does not correspond to the hierarchical distance Hofstede observed in Western countries. A kind of moral obligation between the two categories shades the asymmetry. "Phu Yai" has to provide assistance and support to "Phu Noi" in exchange of these signs of respect. In other words, the legitimacy of a "Phu Yai" is tied to his social role as well as his hierarchical position. In such a context, the "assimilation" between the IS and the communication process revealed a problem of trust of the employees toward SAP. The process automation induced by the use of the ERP reduced face-to-face communications and private codified nonverbal communications. Moreover, information sharing using the IT was no more interpersonal but was actually the result of transparent cross-functional processes. During our interviews, the project director revealed that this was creating a problem of legitimacy in communicating with superiors.

"There is a problem of user confidence in the ERP. Although we showed them that SAP is more sophisticated than the IT they had used, they are wary about the fact that the data to be entered on the electronic forms are effectively communicated to their hierarchical superiors system as they had did directly so far." (Project manager).

These results must not be amalgamated to the principles of the Richness Media Theory (Daft \& Lengel, 1986), or research that observed reduction of confidence in IT-based transactions (Ba \& Pavlou, 2002). In Thailand, face-to-face communications play an important role in building and maintaining the social legitimacy of hierarchical superiors. Facial expressions are used to express negative feelings without being forced to verbalize them. Specialists of Thai culture report 13 different types of codified smiles expressing particular feelings (joy, sadness, annoyance, embarrassment, disagreement, etc.) (Holmes \& Tangtongtavy, 2000; Joungtrakul, 2004). This non-verbal communication is used to positively express both good and bad feelings and relates to the "Kreng Jai" Buddhist principle. "Kreng Jai" is considered as the most influential cultural characteristic on Thai people behaviors (Komin, 1990). Often translated as "the respectful heart," the "Kreng Jai" is synonym of politeness and respect. A person who would fall into the temptation of openly expressing anger or dispute would be self-dishonored. With difference to Western culture, Thai people make no real difference between the ideas defended by a person and the person itself. In other words, explicitly criticizing a position or the choice of a person means making a judgment about that person. As a consequence, one challenge for Thai people is always "saving the face" when a conflict appears (with a person of a lower or higher social rank). The different forms of smiles used in face-to-face communications are parts of the information that interlocutors decode to perceive any consents or dissents. A conflict situation represents a frustrating situation for Thai and has to be absolutely avoided. If such a situation rises anyway, it is likely very difficult to recover from it.

Data revealed that the ERP was ultimately implemented and accepted despite apparent cultural incompatibilities. However, users' acts of resistance were expressed using with a "Thai style" where resisting does not mean openly expressing dissatisfactions nor avoiding what one has to do. The consultant respondent of the company explained that while employees did not ask for any module customizations, they were however expecting top managers to play their role of Phu Yai and give compensations for SAP usage.

"Some of the users were stressed because of the constraints they had to cope with an the time they spent to learn by themselves how using SAP. However, nobody afforded to see the boss and to say 'hey, we met trouble with your SAP and that's wrong'. It doesn't work like this in Thailand! At Eastwater, when SAP has been implemented, the consultants explained to users how they had to proceed with the new system. After, they had a form to fill about the tests to do, their agreement of the functionalities and their remarks. Some of them, the younger ones especially, used this paper to express their expectations in terms of job counterparts for the efforts they did. Some of them even refused to sign the paper. As a consequence, top managers granted training, career plan, and/or financial incentives, to some of them."

Even if one could consider these advantages as symbolic rewards for employees' efforts, form a cultural perspective they represented some kind of moral counterpart to the Bunkhun principle shaping relationships between project stakeholders.

\section{Discussion}

This research and the above results are linked to a limited set of interviews that reflect solely the take of the managers. We do not pretend to fully embrace the concept of "cultural intelligence", however, our results are indicative that it can be possible to theorize on the role of cultural intelligence in explaining users' reactions to ERP implementation and to better explain how such a change can be managed positively.

For practitioners, our empirical analysis gives an illustration of change management during ERP implementation that fully contrasts with the general guidelines. The users' dissatisfaction that was identified was, at first glance, 
functional-oriented, which is in line with the ones often observed in the literature about resistance to ERP. At the same time however, the interviews suggested that this resistance was closely related to the cultural practices of the company in terms of management. They had their source in Buddhist values about (1) the relation to time and (2) the communication modes between individuals and especially between employees and top managers. These observations are in part consistent with empirical research highlighting the contradictions that an ERP project can induce on the ideological values of stakeholders (Bhattacherjee et al., 2008; Bhattacherjee \& Hikmet, 2007; Kohli \& Kettinger, 2004). One difference in the case of Eastwater however is the fact that resistance was less caused by the subcultures of different groups of employees than based on philosophical or religious values of the Buddhist culture as a whole. Another difference is that these values did not involve open conflicts, since these are considered a form of disgrace that is to be avoided in order to "save face".

For researchers, our study put forward the interest of the "cultural intelligence" concept of Earley and Ang (2002). While it had been largely used in cross-cultural team analysis, we here apply the concept of cultural intelligence to apprehend the cultural changes that are involved in an ERP project implementation. Our results show how cultural values shared by employees were used as change management vectors, showing for example how the project director used the "Bunkhun" values to legitimate the ERP adoption and force users' acceptance of the ERP. From this perspective, the Thai culture can be perceived as being paradoxical or ambivalent. On the one hand, its values seem not to be congruent with the ones involved by the ERP project. On the other hand, the strong respect of employees toward their "protectors" (e.g. top managers) paves the way to the adoption. The legitimacy structure, where top managers dominate and trump users' dissatisfaction, was conducive to a successful vanilla implementation. In other cultural contexts, one could imagine that the ERP would have been more customized to users' needs in order to reach a consensus. Our results are in line with empirical research that did not find a significant negative effect national culture in ERP adoption (Krumbholz, Galliers, Coulianos, \& Maiden, 2000). Our case study actually expands the observations of Brown et al. (2002), Robey et al. (2002) who observed that a misfit between firm properties and IT project were not true obstacle to users' acceptance. In other words, users' acts of resistance should not always be considered as the opposite of IT acceptance (van Offenbeek, Boonstra, \&Seo 2012).

\section{Conclusion}

The objective of this article was to identify and analyze potential cultural misfits in the case of ERP project implementations. Thailand represents a suitable research field on both economical and cultural aspects. We presented ERP as a "western cultural artifact" likely to induce inconsistent managerial practices with Buddhist and Thai managerial values. However, we tried to go beyond a simple description highlighting cultural differences. Indeed, we analyzed our data to show how a fit can be reached in IS project management. The research perspectives we adopted do not cover the endless spectrum of social, philosophical and religious assumptions that are likely to shape user resistance. However, they allowed us to focus on key issues that are specific to ERP project implementation in terms of change management. While a large part of the literature considers packaged software as being an inherent source of conflicts for firms because of their mandating pre-established managerial processes, we here suggest an alternative approach that considers the expected cultural fit as more related to the way ERP projects are managed than about the way the systems are designed. This provides a step toward ensuring "cultural intelligence" in IS project management.

Despite the worldwide economy globalization, the management of cultural differences is still perceived more as creating problems rather than as being a source of potential advantages (Komin, 1990; Niffenegger et al., 2006). "Cultural intelligence" lies first and foremost in the organizational capacity to learn from foreign managerial practices without considering this as a renunciation of existing values and beliefs. A project that implies the assimilation of foreign business practices requires the ability for managers to learn the values and beliefs on which cultural differences are based. Managers also have to make sense of their potential congruence with the ones endorsed by the organization. In projects that involve the implementation of a technology (like ERP), which represents a western cultural artifact, one major challenge for managers is ensuring its legitimacy toward the stakeholders. While a common consideration about IT acceptance is related to the technology customization to user needs, we adopt here a different perspective putting forward the challenge of legitimating changes involved in harmony with organizational culture.

\section{References}

Alavi, M., \& Leidner, D. E. (2001). Review: Knowledge Management and Knowledge Management Systems: Conceptual Foundations and Research Issues. MIS Quarterly, 25(1), 107-136. http://dx.doi.org/10.2307/3250961 
Alavi, M., Kayworth, T., \& Leidner, D. E. (2005). An Empirical Examination of the Influence of Organizational Culture on Knowledge Management Practices. Journal of Management Information Systems, 22(3), 191-224. http://dx.doi.org/10.2753/MIS0742-1222220307

Ang, S., \& Inkpen, A. C. (2008). Cultural Intelligence and Offshore Outsourcing Success: a Framework of Firm-Level Intercultural Capability. Decision Sciences, 39(3), 337-358. http://dx.doi.org/10.1111/j.1540-5915.2008.00195.x

Ba, S., \& Pavlou, P. A. (2002). Evidence of the Effect of Trust Building Technology in Electronic Markets: Price Premiums and Buyer Behavior. MIS Quarterly, 26(3), 243. http://dx.doi.org/10.2307/4132332

Bernard, J. G., Rivard, S., \& Aubert, B. A. (2004). L'exposition au risque d'implantation d'ERP: éléments de mesure et d'atténuation. Systèmes d'Information et Management, 9(2), 25-50.

Besson, P., \& Rowe, F. (2001). ERP project dynamics and enacted dialogue: Perceived understanding, perceived leeway, and the nature of task-related conflicts. Database for Advances in Information Systems, 32(4), 47-66. http://dx.doi.org/10.1145/506139.506145

Bhattacherjee, A., \& Hikmet, N. (2007). Physicians' resistance toward healthcare information technology: a theoretical model and empirical test. European Journal of Information Systems, 16(6), 725-737. http://dx.doi.org/10.1057/palgrave.ejis.3000717

Bhattacherjee, A., Davis, C., Hikmet, N., \& Kayhan, V. (2008). User Reactions to Information Technology: Evidence from the Healthcare Sector. In International Conference on Information Systems. Paris, France.

Bloor, G., \& Dawson, P. (1994). Understanding professional culture in organizational context. Organisation Studies, 15(2), 275-295. http://dx.doi.org/10.1177/017084069401500205

Bourdieu, P. (1979). Le sens commun. Paris: Les éditions de minuit.

Boyatzis, R. (1998). Transforming qualitative information: thematic analysis and code development. California: Sage.

Brown, S. A., Massey, A. P., Montoya-Weiss, M. M., \& Burkman, J. R. (2002). Do I really have to? User acceptance of mandated technology. European Journal of Information Systems, 11(4), 283. http://dx.doi.org/10.1057/palgrave.ejis.3000438

Corbitt, B., Peszynski, K., Inthanond, S., Hill, B., \& Thanasankit, T. (2004). Cultural Differences, Information and Code Systems. Journal of Global Information Management, (3), 65-85. http://dx.doi.org/10.4018/jgim.2004070104

d'Iribarne, P. (1989). La logique de l'honneur. Gestion des entreprises et traditions nationales. Seuil.

Daft, R. L., \& Lengel, R. H. (1986). Organizational Information Requirements, Media Richness and Structural Design. Management Science, 32(5), 554-571. http://dx.doi.org/10.1287/mnsc.32.5.554

Davenport, T. H. (1998). Putting the Enterprise into the Enterprise System. Harvard Business Review, 76(4), $121-131$.

Davis, F. D. (1989). Perceived Usefulness, Perceived Ease of Use, and User Acceptance of Information Technology. MIS Quarterly, 13(3), 318. http://dx.doi.org/10.2307/249008

Davis, F. D., Bagozzi, R. P., \& Warshaw, P. R. (1992). Extrinsic and Intrinsic Motivation to Use Computers in the Workplace. Journal of Applied Social Psychology, 22(14), 1111-1132. http://dx.doi.org/10.1111/j.1559-1816.1992.tb00945.x

Dougherty, D. (1992). Interpretative Barriers to Successful Product Innovation in Large Firms. Organization Science, 3(2), 179-202. http://dx.doi.org/10.1287/orsc.3.2.179

Drucker, P. (1998). Managing in a time of great change. New York: Dutton/Plume.

Dubé, L. (1998). Teams in packaged software development: The Software Corp. experience. Information Technology \& People, 11(1), 36-61. http://dx.doi.org/10.1108/09593849810204530

Earley, P. C., \& Ang, S. (2002). Cultural Intelligence - Individual Interactions Across Cultures. Palo Alto, CA USA: Stanford University Press.

Earley, P. C., \& Mosakowski, E. (2000). Creating hybrid team cultures: an empirical test of transnational team functioning. Academy of Management Journal, 43, 26-49. http://dx.doi.org/10.2307/1556384

Eisenhardt, K. M. (1989). Building theories from case study research. Academy of Management Review, 14(4), 
532-550.

El Sawy, O. A. (1985). Implementation by Cultural Infusion: An Approach for Managing the Introduction of Information Technologies. MIS Quarterly, 9(2), 131-140. http://dx.doi.org/10.2307/249114

Feldman, M. S., \& March, J. G. (1991). L'information dans les organisations: un signal et un symbole. In J. G. March (Ed.), Les Editions d'Organisation.

Gilbert, P., \& Leclair, P. (2004). Les systèmes de gestion intégrés. Une modernité en trompe l'œil ? Sciences de La Société, (61), 17-30.

Gold, A. H., Malhotra, A., \& Segars, A. H. (2001). Knowledge management: An organizational capabilities perspective. Journal of Management Information Systems, 18(1), 185-214.

Gregory, R. P. M. B. R., Prifling, M., \& Beck, R. (2009). The role of cultural intelligence for the emergence of negotiated culture in IT offshore outsourcing projects. Information Technology \& People, 22(3), 223-241. http://dx.doi.org/10.1108/09593840910981428

Hall, E. T. (1959). The silent language. Garden City, NY: Doubleday.

Hall, E. T. (1981). Beyond culture. New York: Doubleday.

Handley, K., Sturdy, A., Fincham, R., \& Clark, T. (2006). Within and Beyond Communities of Practice: Making Sense of Learning Through Participation, Identity and Practice. Journal of Management Studies, 43(3), 641-653. http://dx.doi.org/10.1111/j.1467-6486.2006.00605.x

Hill, C., Loch, K., Straub, D. W., \& El-Sheshai, K. (1998). A Qualitative Assessment of Arab Culture and Information Technology Transfer. Journal of Global Information Management, 6(3), 29-38. http://dx.doi.org/10.4018/jgim.1998070103

Hirschheim, R., \& Newman, M. (1991). Symbolism and Information Systems Development: Myth, Metaphor and Magic. Information Systems Research, 2(1), 29-62. http://dx.doi.org/10.1287/isre.2.1.29

Hoffman, N. (2000). Assimilating new technologies. Information Systems Management, (3), 36. http://dx.doi.org/10.1201/1078/43192.17.3.20000601/31239.6

Hofstede, G. (1991). Culture and organizations: software of the mind. McGraw Hill.

Hofstede, G., \& Bond, M. H. (1988). The Confucius connection: From cultural roots to economic growth. Organizational Dynamics, 16(4), 5-21. http://dx.doi.org/10.1016/0090-2616(88)90009-5

Holmes, H., \& Tangtongtavy, S. (2000). Working With the Thais: A Guide to Managing in Thailand. Bangkok: White Lotus Co.

Hung, S. Y., Yu, W. J., Chen, C., \& Hsu, J. C. (2012). Managing ERP Success by Enhancing Key Project Management And Organizational Fit Factors, PACIS 2012 Proceedings (2012).

Jarvenpaa, S. L., \& Leidner, D. E. (1998). An Information Company in Mexico: Extending the Resource-Based View of the Firm to a Developing Country. Information Systems Research, 9(4), 342-361. http://dx.doi.org/10.1287/isre.9.4.342

Jermier, J. M., Slocum, J. W., Fry, L. W., \& Gaines, J. (1991). Organizational subcultures in a soft bureaucracy: Resistance behind the myth and façade of an official culture. Organization Science, 2(2), 170-194. http://dx.doi.org/10.1287/orsc.2.2.170

Jiang, J. J., Muhanna, W. A., \& Klein, G. (2000). User resistance and strategies for promoting acceptance across system types. Information \& Management, 37(1), 25-36. http://dx.doi.org/10.1016/S0378-7206(99)00032-4

Joshi, K. (1992). A Causal Path Model of the Overall User Attitudes Toward the MIS Function: The Case of User Information Satisfaction. Information $\quad \& \quad$ Management, 22(2), 77-88. http://dx.doi.org/10.1016/0378-7206(92)90063-L

Joungtrakul, J. (2004). The Cultural Dimensions of Business Management in Thailand. Bangkok.

Joungtrakul, J. (2009). Industrial Democracy and Best Practice in Thailand. Germany: LAP Lambert Academic Publishing.

Kappos, A., \& Rivard, S. (2008). A Three-Perspective Model Of Culture, Information Systems, and Their Development and Use. MIS Quarterly, 32(3), 601-634.

Karahanna, E., Evaristo, J. R., \& Srite, M. (2005). Levels of Culture and Individual Behavior: An Integrative Perspective. Journal of Global Information Management, 13(2), 1-20. 
http://dx.doi.org/10.4018/jgim.2005040101

Kendall, K. (1997). The significance of information systems research on emerging technologies: Seven information technologies that promise to improve managerial effectiveness. Decision Sciences, 28(4), 775-792. http://dx.doi.org/10.1111/j.1540-5915.1997.tb01331.x

Klausner, W. J. (1998). Thai culture in transition. The Siam Society.

Kohli, R., \& Kettinger, W. J. (2004). Informating the Clan: Controlling Physicians' Costs and Outcomes. MIS Quarterly, 28(3), 363-394.

Komin, S. (1990). The Psychology of the Thai People: Values and Behevioral Patterns. Bangkok: NIDA.

Krumbholz, M., Galliers, J., Coulianos, N., \& Maiden, N. A. M. (2000). Implementing enterprise resource planning packages in different corporate and national cultures. Journal of Information Technology, 15(4), 267-280. http://dx.doi.org/10.1080/02683960010008962

Kwahk, K. Y., \& Lee, J. N. (2008). The role of readiness for change in ERP implementation: Theoretical bases and empirical validation. Information \& Management, 45(7), 474-481. http://dx.doi.org/10.1016/j.im.2008.07.002

Lee, J. C., \& Myers, M. D. (2004). Dominant actors, political agendas, and strategic shifts over time: a critical ethnography of an enterprise systems implementation. The Journal of Strategic Information Systems, 13(4), 355-374. http://dx.doi.org/10.1016/j.jsis.2004.11.005

Leidner, D. E., \& Kayworth, T. (2006). Review: a Review of Culture in Information Systems Research: Toward a Theory of Information Technology Culture Conflict. MIS Quarterly, 30(2), 357-399.

Lim, E. T. K., Shan Ling, P., \& Chee Wee, T. (2005). Managing user acceptance towards Enterprise Resource planning (ERP) systems - understanding the dissonance between user expectations and managerial policies. European Journal of Information Systems, 14(2), 135-149. http://dx.doi.org/10.1057/palgrave.ejis.3000531

Markus, M. L., \& Robey, D. (1983). The Organizational Validity of Management Information Systems. Human Relations, 36(3), 203-226. http://dx.doi.org/10.1177/001872678303600301

Markus, M. L., Axline, S., Petrie, D., \& Tanis, C. (2000). Learning from adopters' experiences with ERP: problems encountered and success achieved. Journal of Information Technology, 15(4), 245-265. http://dx.doi.org/10.1080/02683960010008944

Markus, M. L., Tanis, C., \& Fenema, P. C. van. (2000). Multisite ERP implementations. Communications of the ACM, 43(4), 42-46. http://dx.doi.org/10.1145/332051.332068

Martin, J. (2002). Organizational Culture: Mapping the Terrain. Thousand Oaks, CA: Sage.

Meissonier, R., \& Houzé, E. (2010). Toward an "IT Conflict-Resistance Theory": action research during IT pre-implementation. European Journal of Information Systems, 19(5), 540-561. http://dx.doi.org/10.1057/ejis.2010.35

Meissonier, R., Houzé, E., \& Bessière, V. (2013). Cross-Cultural Frictions in Information System Management: Research Perspectives on ERP Implementation Misfits in Thailand. International Business Research, 6(2).

Meyerson, D., \& Martin, J. (1987). Cultural change: an integration of three different views. The Journal of Management Studies, 24(6), 623-647. http://dx.doi.org/10.1111/j.1467-6486.1987.tb00466.x

Miles, M., \& Huberman, M. (1984). Qualitative data analysis: A source book for new methods. Sage Publications.

Moores, T. T., \& Gregory, F. H. (2000). Cultural problems in applying SSM for IS development. Journal of Global Information Management, 8(1), 14-19. http://dx.doi.org/10.4018/jgim.2000010102

Myers, M. D., \& Tan, F. B. (2002). Beyond models of national culture in information systems research. Journal of Global Information Management, 10(1), 24-32. http://dx.doi.org/10.4018/jgim.2002010103

Ngwenyama, O. K., \& Nielsen, P. A. (2003). Competing values in software process improvement: an assumption analysis of CMM from an organizational culture perspective. IEEE Transactions on Engineering Management, 50(1), 101-111. http://dx.doi.org/10.1109/TEM.2002.808267

Niffenegger, P., Kulviwat, S., \& Engchanil., N. (2006). Conflicting Cultural Imperatives in Modern Thailand: Global Perspectives. Asia Pacific Business Review, 12(4), 403-420. http://dx.doi.org/10.1080/13602380600571211

Orlikowski, W. J. (1992). The Duality of Technology: Rethinking the Concept of Technology in Organizations. 
Organization Science, 3(3), 398-427. http://dx.doi.org/10.1287/orsc.3.3.398

Ouchi, W. G. (1978). Hierarchies, Clans and Theory Z: A New Perspective on Organization Development. Administrative Science Quarterly.

Reckwitz, A. (2002). Toward a theory of social practices: a development in culturalist theorizing. European Journal of Social Theory, 5(2), 245-265. http://dx.doi.org/10.1177/13684310222225432

Rivard, S., \& Lapointe, L. (2012). Information Technology Implementers' Responses to User Resistance: Nature and Effects. MIS Quarterly, 36(3), 897-A5.

Robey, D., \& Markus, M. L. (1984). Rituals In Information System Design. MIS Quarterly, 8(1), 5-15. http://dx.doi.org/10.2307/249240

Robey, D., Ross, J. W., \& Boudreau, M. C. (2002). Learning to Implement Enterprise Systems: An Exploratory Study of the Dialectics of Change. Journal of Management Information Systems, 19(1), 17-46.

Rockart, J. F., \& Short, J. E. (1995). The networked organization and the management of interdependence. In M. S. Scott-Morton (Ed., pp. 189-219). New York: University Press.

Sainsolieu, R. (1995). Sociologie de l'entreprise: organisation, culture et développement (Dalloz.).

Schein, E. H. (1984). Coming to a New Awareness of Organizational Culture. Sloan Management Review (pre-1986), 25(2), 3.

Seddon, P., Calvert, C., \& Yang, S. (2010). A Multi-Project Model of Key Factors Affecting Organizational Benefits from Enterprise Systems. MIS Quarterly, 34(2), 305-340.

Selvarajaha, C., Meyerb, D., \& Donovan, J. (2013). Cultural context and its influence on managerial leadership in Thailand - ProQuest. Asia Pacific Business Review, 19(3), 356-380. http://dx.doi.org/10.1080/13602381.2012.714630

Shenkar, O., Luo, Y., \& Yeheskel, O. (2008). From "distance" to "friction": substituting metaphors and redirecting intercultural research. Academy of Management Review, 33(4), 905-923. http://dx.doi.org/10.5465/AMR.2008.34421999

Stewart, K. J., \& Gosain, S. (2006). The Impact of Ideology on Effectiveness in Open Source Software Development Teams. MIS Quarterly, 30(2), 291-314.

Straub, D. W. (1994). The Effect of Culture on It Diffusion - E-Mail and Fax in Japan and the United-States. Information Systems Research, 5(1), 23-47. http://dx.doi.org/10.1287/isre.5.1.23

Straub, D. W., Keil, M., \& Brenner, W. (1997). Testing the technology acceptance model across cultures: A three country study. Information \& Management, 33(1), 1-11. http://dx.doi.org/10.1016/S0378-7206(97)00026-8

Straub, D. W., Loch, K. D., \& Evaristo, J. R. (2002). Toward a theory-based measurement of culture. Journal of Global Information Management, 10(1), 13-23. http://dx.doi.org/10.4018/jgim.2002010102

Strong, D. M., \& Volkoff, O. (2010). Understanding Organization-Enterprise System Fit: a Path to Theorizing the Information Technology Artifact. MIS Quarterly, 34(4), 731-756.

Teece, D. J. (2003). Knowledge and competence as strategic assets. In C. W. Holsapple (Ed.), Handbook on Knowledge Management, Volume 1: Knowledge Matters (pp. 129-152). Heidelberg: Springer- Verlag.

Thanasankit, T. (2002). Requirements engineering —exploring the influence of power and Thai values. European Journal of Information Systems, 11(2), 128-141. http://dx.doi.org/10.1057/palgrave/ejis/3000423

Thanasankit, T., \& Corbitt, B. (2000). Thai culture and communication of decision-makig processes in requirements engineering. In 2nd International Conference on Culture Attitudes Towards Technology and Communication (pp. 217-242). Murdoch University, Australia.

Thomas, D. C. (2006). Domain and development of cultural intelligence: the importance of mindfulness. Group \& Organization Management, 31(1), 78-99. http://dx.doi.org/10.1177/1059601105275266

Thomas, D. C., \& Inkson, K. (2004). Cultural Intelligence: People skills for global business. New York: Wiley.

Thompson, V. A. (1961). Modern Organization. New-York: Knopf.

Trauth, E. M. (2000). The culture of an information economy: influences and impacts in the Republic of Ireland. London: Dordrecht. http://dx.doi.org/10.1007/978-94-010-9836-6

Trauth, E. M., \& Thomas, R. S. (1993). Electronic data interchange: A new frontier for global standards policy. 
Journal of Global Information Management, 1(4), 6-27. http://dx.doi.org/10.4018/jgim.1993100101

Urquhart, C., Lehmann, H., \& Myers, M. D. (2009). Putting the "theory" back into grounded theory: guidelines for grounded theory studies in information systems. Information Systems Journal, 20(4), 357-381. http://dx.doi.org/10.1111/j.1365-2575.2009.00328.x

Van Vuuren, I. J., \& Seymour, L. F. (2013). Towards a model for user adoption of enterprise systems in SMEs. In Proceedings of the First International Conference on Enterprise Systems: ES 2013 (pp. 1-9). IEEE.

Vance, A., Elie-Dit-Cosaque, C., \& Straub, D. W. (2008). Examining Trust in Information Technology Artifacts: The Effects of System Quality and Culture. Journal of Management Information Systems, 24(4), 73-100. http://dx.doi.org/10.2753/MIS0742-1222240403

Vatanasakdagul, S., D'Ambra, J., \& Ramburuth, P. (2010). IT Doesn't Fit! The Influence of Culture on B2B in Thailand. Journal of Global Information Technology Management, 13(3), 10-38. http://dx.doi.org/10.1080/1097198X.2010.10856518

Venkatesh, V. D. (1994). Modeling the Determinants of Perceived Ease of Use (pp. 213-227). Vilamoura, Portugal.

Wagner, E., \& Newell, S. (2004). Best for whom?: the tension between best practice ERP packages and diverse epistemic cultures in a university context. Journal of Strategic Information Systems, 13, 305-328. http://dx.doi.org/10.1016/j.jsis.2004.11.002

Walczuch, R., Lemmink, J., \& Streukens, S. (2007). The effect of service employees' technology readiness on technology acceptance. Information \& Management, 44(2), 206-215. http://dx.doi.org/10.1016/j.im.2006.12.005

Walsham, G. (2002). Cross-cultural software production and use: A structurational analysis. MIS Quarterly, 26(4), 359-380. http://dx.doi.org/10.2307/4132313

Walton, R. E., Dutton, J. M., \& Cafferty, T. P. (1969). Organizational Context and Interdepartmental Conflict. Administrative Science Quarterly, 14(4), 522-543. http://dx.doi.org/10.2307/2391590

Weber, Y., \& Pliskin, N. (1996). The effects of information systems integration and organizational culture on a $\begin{array}{llll}\text { firm's effectiveness. Information } \quad \& \quad \text { Management, } & 30(2), & 81-90 .\end{array}$ http://dx.doi.org/10.1016/0378-7206(95)00046-1

Weick, K. E. (1988). Enacted Sensemaking in Crisis Situations. Journal of Management Studies, 25(4), 305-317. http://dx.doi.org/10.1111/j.1467-6486.1988.tb00039.x

Wenger, E., McDermott, R., \& Snyder, W. M. (2002). Cultivating Communities of Practice. Boston: Harvard Business School Press.

Yin, R. (1994). Case study research: Design and methods. Beverly Hills: Sage Publishing.

Yukongdi, V. (2010). A study of Thai employees' preferred leadership style. Asia Pacific Business Review, 16(2), 161-181. http://dx.doi.org/10.1080/13602380903168962

\section{Copyrights}

Copyright for this article is retained by the author(s), with first publication rights granted to the journal.

This is an open-access article distributed under the terms and conditions of the Creative Commons Attribution license (http://creativecommons.org/licenses/by/3.0/). 